\title{
Patterns of species richness and composition of fish assemblages in streams of the Ivinhema River basin, Upper Paraná River
}

\author{
Padrôes de riqueza e composição de espécies das assembleias de \\ peixes em riachos da bacia do rio Ivinhema, Alto Rio Paraná
}

Yzel Rondon Súarez ${ }^{1}$, Marcelo Maldonado de Souza ${ }^{1}$, Fabiane Silva Ferreira ${ }^{1}$,

Maiane Jardim Pereira ${ }^{1}$, Ediléia Amancio da Silva ${ }^{1}$, Lidiani Queli Lubas Ximenes ${ }^{2}$,

Luciana Gonçalves de Azevedo ${ }^{1}$, Olemar Cáceres Martins ${ }^{1}$ and Sidnei Eduardo Lima Júnior ${ }^{1}$

${ }^{1}$ Laboratório de Ecologia - CInAM, Universidade Estadual de Mato Grosso do Sul - UEMS, Rod. Dourados-Itahum, Km 12, CEP 79804-970, Dourados, MS, Brazil

${ }^{2}$ Programa de Pós-Graduação em Ecologia e Conservação, Universidade Federal de Mato Grosso do Sul - UFMS, Brazil e-mail: yzel@uems.br, marceloitahum@gmail.com, fabianesfbio@gmail.com, jardin_maiane@yahoo.com.br, edileia.amancio@hotmail.com, lqueli@hotmail.com, pantalu69@hotmail.com, olemarcaceres_m007@hotmail.com, selimajunior@hotmail.com

\begin{abstract}
Aim: The present study analyzed the spatial variation in fish species richness and composition in streams of the Ivinhema River basin, Upper Paraná basin, determining the relationship between local and regional descriptors of the fish assemblage organization; Method: From 2001 to 2011 we sampled 200 stream stretches, using different sampling methods. Local species richness and composition were analyzed using univariate and multivariate methods to detect patterns of variation in the fish assemblage organization; Results: We identified 111 fish species in the streams, and estimated the occurrence of 117 fish species $\left(\mathrm{CI}_{\alpha 0.05}=111\right.$ to 123$)$ with lower species richness in headwater streams compared to the lower parts of the basin. The fish species recorded were predominantly of small size, and the mean size increased from the headwaters to the river mouth. The four most common species are widely distributed in the basin. However, 24 species are allocthonous to the Upper Paraná basin, and two species (Chaetobranchopsis australis and Apistogramma commbrae) are recorded here for the first time in the Upper Paraná basin. Altitude was the main determinant of local fish species richness and composition, and a discontinuity in assemblage organization (richness, composition, fish size) was detected at approximately $430 \mathrm{~m}$ a.s.l.; Conclusion: Streams of the Ivinhema River basin are inhabited mainly by small-sized fishes; and longitudinal variation, interacting with local characteristics, determines the fish assemblage patterns.
\end{abstract}

Keywords: altitudinal gradient, neotropical region, assemblage organization, environmental filters.

Resumo: Objetivos: O presente estudo tem como objetivo analisar a variação especial na riqueza e composição de espécies de peixes em riachos da bacia do rio Ivinhema, Alto Rio Paraná determinando a relação entre características locais e regionais na organização das assembleias de peixes; Métodos: Amostramos 200 trechos de riachos entre $2001 \mathrm{e}$ 2011 utilizando diferentes petrecho de pesca. A riqueza local e composição de espécies foram analisadas utilizando métodos uni e multivariados buscando detectar padróes na organização das assembleias de peixes; Resultados: Identificamos 111 espécies de peixes nos riachos amostrados e estimamos a ocorrência de 117 espécies de peixes $\left(\mathrm{IC}_{\alpha 0,05}=111\right.$ a 123) com menor riqueza de espécies nos trechos de cabeceira quando comparados aos trechos inferiores da bacia. As espécies de peixes registradas são predominantemente de pequeno porte, com incremento no tamanho médio das nascentes para a foz do rio. As quatro espécies mais comuns são de ampla distribuição na bacia, no entanto, 24 espécies são alóctones ao Alto Rio Paraná e duas espécies (Chaetobranchopsis australis e Apistogramma commbrae) são registradas pela primeira vez na bacia do Alto Rio Paraná. A altitude foi o principal determinante da riqueza e composição de espécies e uma descontinuidade na organizaçáo das assembleias (riqueza, composição e tamanho dos peixes) foi detectada a aproximadamente $430 \mathrm{~m}$ de altitude; Conclusóes: Os riachos da bacia do rio Ivinhema apresentam principalmente espécies de pequeno porte e a variação de altitude, interagindo com fatores locais, determinam os padrôes observados nas assembleias de peixes.

Palavras-chave: gradiente altitudinal, regiáo neotropical, organização das assembleias, filtros ambientais. 


\section{Introduction}

Knowledge of the basic characteristics of biological assemblages is a first step toward the development of effective conservation policies. For many Brazilian hydrographic basins, the minimum requirement of a list of fish species is lacking, which makes it difficult or impossible to determine any general pattern of variation in species diversity and species-environment relationships.

The number of studies examining largescale spatial patterns of species distribution has increased in the last decade, mainly in temperate regions (Marsh-Matthews and Matthews, 2000; Oberdorff et al., 2001; Grenouillet et al., 2004; Hoeinghaus et al., 2007; Dauwalter et al. 2007; Higgins, 2010). Among the main results of these studies is the quantification of longitudinal gradients interacting with regional (inter-basin) differences in determining fish species richness and composition. In tropical streams fewer studies had realized and usually in smaller hydrographic basins.

The river continuum concept (Vannote et al., 1980) proposed that predictable variations in aquatic communities occur according to their longitudinal position in a hydrographic basin. Therefore, alterations in organic-matter production/ input, combined with the constraining effect of hydrological features (Poff, 1997), can drive species richness and composition by regulating the colonization/extinction rate in each part of the basin.

Among the few studies on large-scale fish species distributions in the Neotropics are those of Bistoni and Hued (2002) on the altitudinal richness gradient in rivers of Argentina; Súarez and Petrere (2003) on the fish species distribution in lotic habitats of the Iguatemi River basin, Upper Paraná basin; Ferreira and Petrere (2009) on stream fish communities in the Itanhaém River basin; and Pinto et al. (2009) on fish ecoregions and local determinants of fish assemblages in the Paraiba do Sul River basin.

The existing studies in many biogeographic regions have suggested that interacting local and regional factors determine fish assemblage patterns. Then, longitudinal variation, together with local characteristics such as water velocity and stream volume, act to selecting species from a regional pool, mainly in headwaters; while in lower portions of the basin, the environmental homogeneity allows the occurrence of many fish species (Taylor and Warren Junior, 2001).
The Upper Paraná River basin is considered an area of endemism for many fish groups, the result of a formidable geographical barrier, until recently formed by the Sete Quedas waterfall, now submerged by the Itaipú Reservoir (Géry, 1969; Britski and Langeani, 1988; Langeani et al., 2007). The number of studies is increasing in the eastern portion of the basin, mainly in the state of São Paulo (Castro et al., 2003; Castro et al., 2004; Castro et al., 2005; Casatti et al., 2006, Teresa and Casatti, 2010); however, the western portion is relatively little studied. A few studies have dealt with fish diversity and composition in rivers and streams of the Iguatemi River basin (Súarez and Petrere Júnior, 2003, 2005, 2006, 2007). In the Ivinhema River basin, some smallscale studies on the headwaters or lower portions of the basin have been carried out (Valério et al., 2007; Súarez, 2008; Súarez and Lima-Júnior, 2009; Felipe and Súarez, 2010); however, no data on the large scale are available for this basin, that would allow understanding the fish species richness and distribution for the basin as a whole.

The present study aimed to describe the general pattern of species richness and composition in the Ivinhema River basin, answering the following questions: 1) How many species occur in streams of the Ivinhema River basin? 2) Does longitudinal variation influence the species richness and composition for Ivinhema River basin? 3) Can environmental descriptors be used to explain local species richness and composition in streams of the Ivinhema River basin?

\section{Materials and Methods}

\subsection{Study area}

The Ivinhema river basin is located to the right bank of the Paraná River, in the Mato Grosso do Sul State, Brazil (Figure 1). With approximately $600 \mathrm{~km}$ long and $45,000 \mathrm{~km}^{2}$ of area, this basin is one de few remaining segment with lotic characteristics in the Upper Paraná basin (without influence of damming). The Ivinhema River source is located approximately to $700 \mathrm{~m}$ of altitude at headwaters of Dourados River, that flows to Brilhante River and with your fusion with Vacaria River has been renamed to Ivinhema.

\subsection{Sampling}

The fish were caught in 200 stream stretches distributed along the entire basin, from 2001 to 2011. The samples were taken mainly with a 


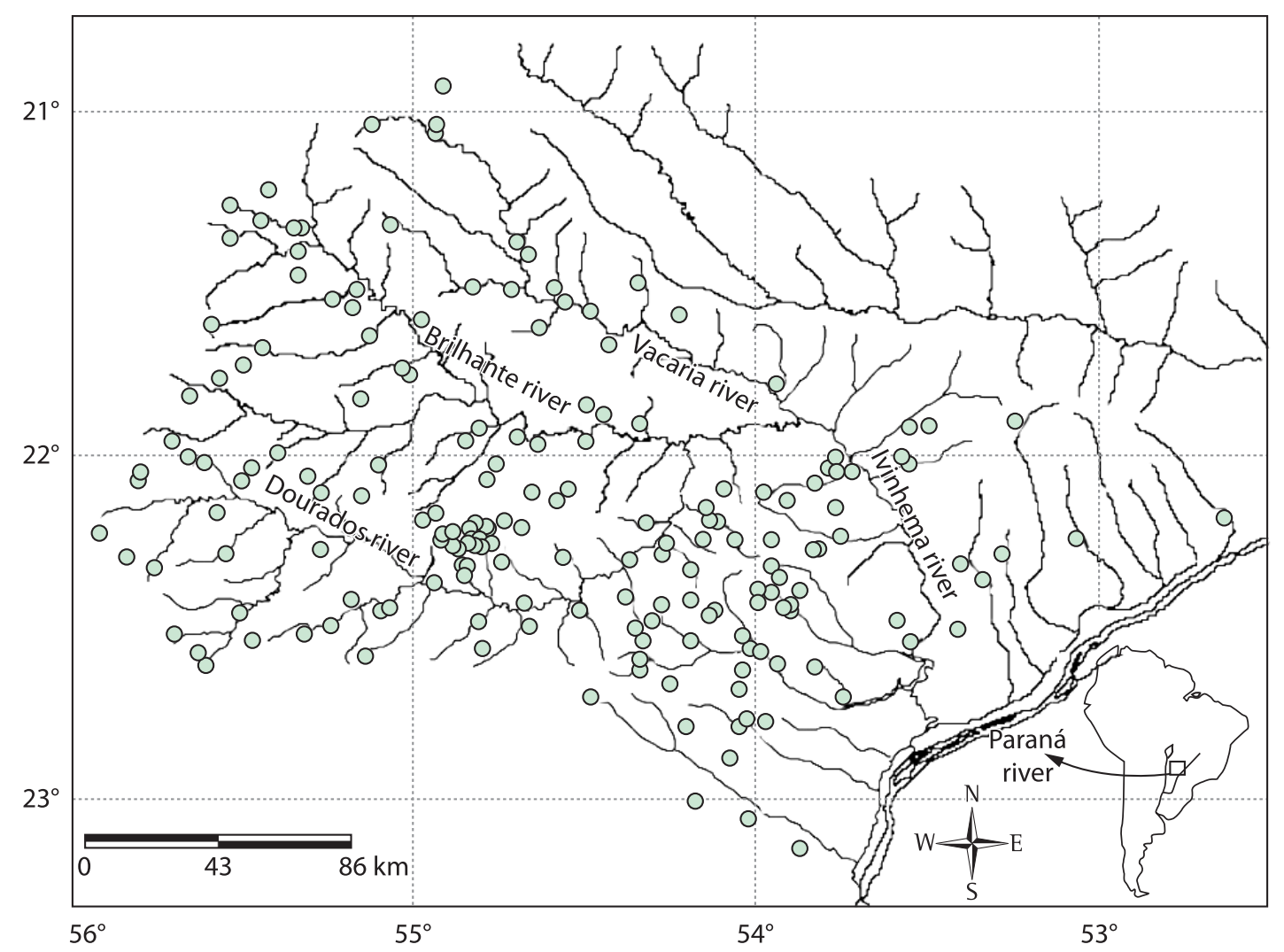

Figure 1. Location of sampled streams at Ivinhema River basin, Upper Paraná basin, from 2001 to 2011.

rectangular sieve measuring $1.2 \times 0.8 \mathrm{~m}(2 \mathrm{~mm}$ mesh size) and electrofishing at each site, with approximately 100-m-long hauls. Streams with larger volume were sampled also, using a seine net $1.5 \times 5 \mathrm{~m}(2 \mathrm{~mm}$ mesh size $)$ and gillnets of different mesh size $(15,20,30,40$ and $50 \mathrm{~mm})$ between adjacent knots. In the field, the fish were fixed in $10 \%$ formalin and preserved in $70 \%$ ethanol for subsequent identification.

At each site a set of environmental variables was obtained, including the geographical coordinates, altitude, stream width, stream depth, water velocity, and water electrical conductivity, using a digital flowmeter and using a digital portable condutivimeter. As result of a long samples period others limnological variables are not available for all sites. Stream depth, width and water velocity were measured at least 5 times, in different portions of the sampling area, and a simple arithmetic mean were used as a descriptor of the stream stretch.

\subsection{Data analysis}

The streams were subdivided into classes of $50 \mathrm{~m}$ of altitude, to compare species richness, size (standard length) and composition along the altitude gradient in the basin. For Gymnotiformes and Synbranchiformes, the total length was used as a measure of size.

The total species richness and the species richness for each altitude class were estimated using the bootstrap procedure (Smith and van Belle, 1984), as well as its confidence interval $(\alpha=0.05)$, using presence/absence data for all samples. This procedure was selected for its robustness, with relatively large sample sizes (Hellmann and Fowler, 1999).

To analyze the influence of environmental variables on local species richness, we performed a regression tree analysis, using the species richness as the response variable and the environmental characteristics as the explanatory variables. The regression tree analysis is a method of partitioning the variability in the response variable, in which the observations are divided into mutually exclusive groups, and these groups are the most homogeneous possible (De'Ath and Fabricius, 2000). Among the advantages of this method are simplicity in the graphical interpretation of the results, and the lack of need to transform the data, as well as the increased parsimony of the results (Turgeon and Rodriguez, 2005). This method efficiently captures the importance of explanatory variables 
that indicate a linear or non-linear influence on the response variable, observed in our data, by initial data inspections.

The frequency of occurrence of each species in an altitudinal gradient was used to generate a cluster analysis, using a Morisita-Horn coefficient and Unweighted Pair Group Method Average (UPGMA) as the ligation method. The cophenetic correlation was used as measure of fidelity of the dendrogram to the initial similarity matrix.

The potential use of the species sampled as an indicator of altimetric groups was performed by Indval analysis (Dufrêne and Legendre, 1997) using a multipatt routine in the indicspecies package (Caceres and Jansen, 2010), and a significance of indicator value was obtained for each species by a randomization procedure (999 permutations).

A gradient in the assemblage and the importance of environmental descriptors were assessed using a Canonical Correspondence Analysis (CCA). Species with a frequency of occurrence of at least $10 \%$ of the total sites sampled were included in this analysis (27 species). This analysis was carried out using an $\mathrm{R}$ package ( $\mathrm{R}$ Development Core Team, 2011) through the cca function in the vegan package (Oksanen et al., 2011). The significance of environmental variables was assessed by the envfit function.

\section{Results}

A total of 111 fish species were collected, with an estimated richness of 117 species $\left(\mathrm{CI}_{0.05}=111\right.$ to 123 ), therefore approximately $95 \%$ of estimated species were sampled. The species richness ranged from zero to 54 species, with a median value of nine fish species. Approximately $45 \%$ of the sampling sites had fewer than nine recorded species (Figure 2). However, the species richness pattern varied according to position in longitudinal gradient, with approximately 20 species recorded in the upper portion of the basin, and more than 90 in streams of the lower portion of the basin (Figure 3), considering accumulated and estimated species richness.

Characiformes predominated, with 54 species (48.6\%) followed by Siluriformes with 38 species (34.2\%), Gymnotiformes with 9 (8.1\%), Perciformes 6 (5.4\%), Cyprinodontiformes 3 $(2.7 \%)$ and Synbranchiformes with 1 (0.9\%). A total of 24 species $(21.6 \%)$ are allocthonous to the Upper Paraná basin, 23 of them from the Neotropics and one from Africa (Tilapia rendalli).

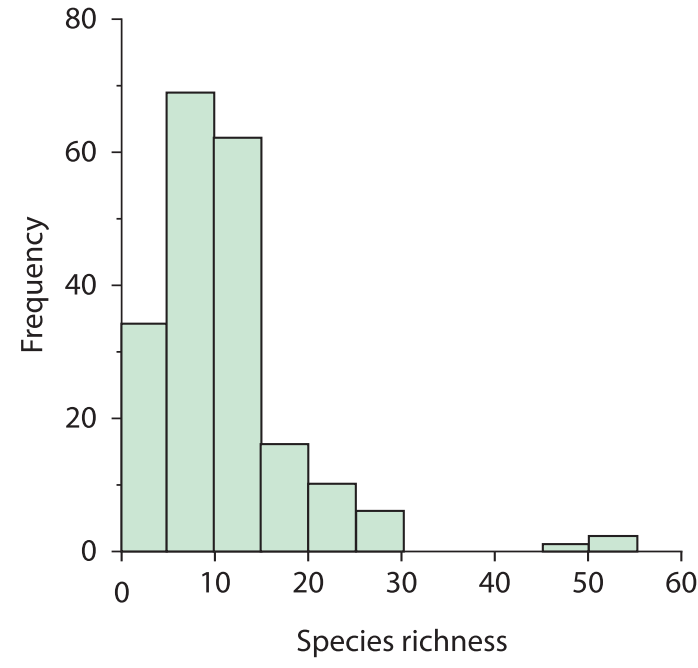

Figure 2. Histogram of fish species richness by sampled stream in Ivinhema river basin, Upper Paraná basin, from 2001 to 2011.

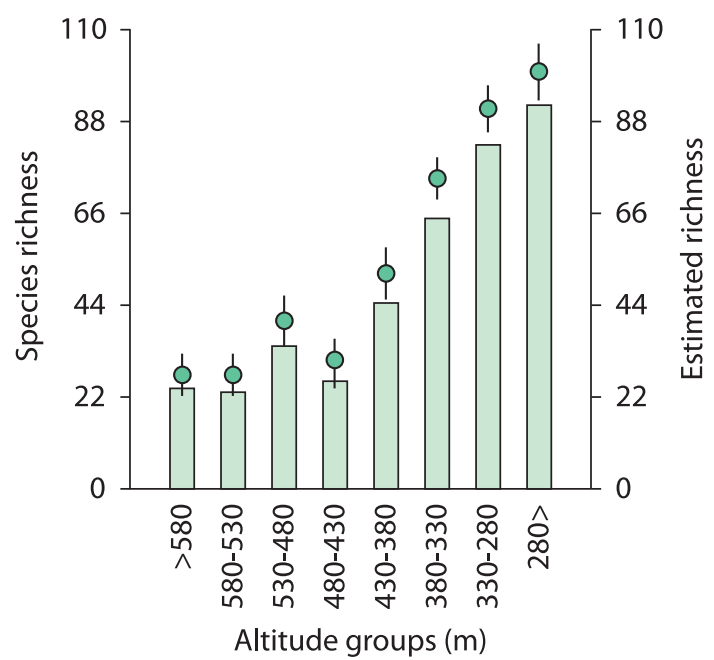

Figure 3. Gradient of species richness (bar) and estimated species richness (circle) with standard error along an altitude groups of sampled streams in Ivinhema River Basin, Upper Paraná basin from 2001 to 2011.

The most common species was Astyanax altiparanae, occurring in 129 sites (64.5\%), followed by Serrapinnus notomelas (113 sites, 56.5\%), Bryconamericus stramineus (109 sites, 54.5\%) and Hypostomus ancistroides (102 sites, 51\%). At least five species are undescribed, and two are recorded here in the Upper Paraná basin for thefor the first time (Chaetobranchopsis australis and Apistogramma commbrae).

The stream fish assemblage was composed mainly by small-sized species, 50 (45\%) smaller than $10 \mathrm{~cm}$ (Figure 4a). The relative predominance of smaller species changed according to the altitudinal gradient at the basin, with an increase of mean size from the headwaters to the lower portion of the basin (Figure 4b). 
The regression tree analysis explained $62.4 \%$ of the variation in species richness data, and altitude was the main determinant of species richness (Figure 5). Streams located at an altitude lower than $308.5 \mathrm{~m}$ and with a mean width larger than $5.36 \mathrm{~m}$ had the highest mean species richness (22.69 species). Streams located above $406.5 \mathrm{~m}$ had the lowest mean species richness (6.67 species).

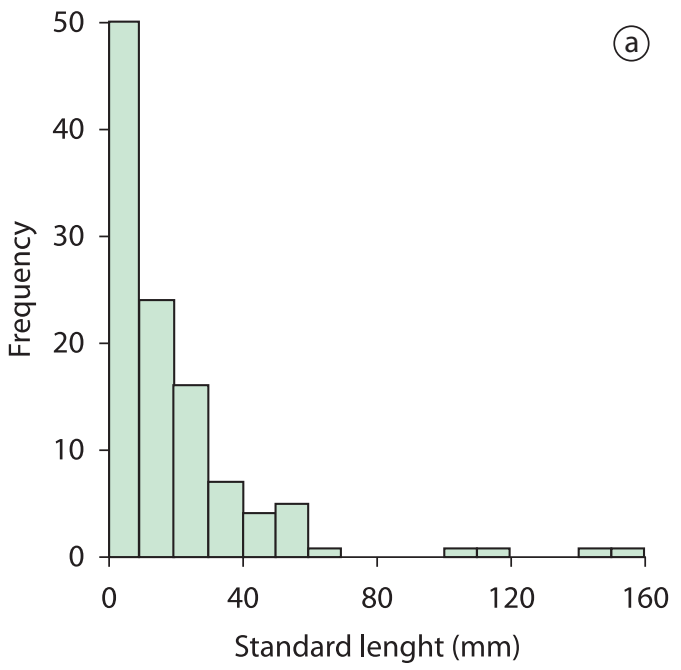

The cluster analysis showed a clear differentiation in the fish assemblages in two altitude groups, below and above $430 \mathrm{~m}$ (Figure 6). This altimetric differentiation concorded with the frequency of occurrence of fish species along the altimetric gradient, generating significant Indicator values for many species. Certain species, including Astyanax fasciatus, Apareiodon ibitiensis, A. piracicabae

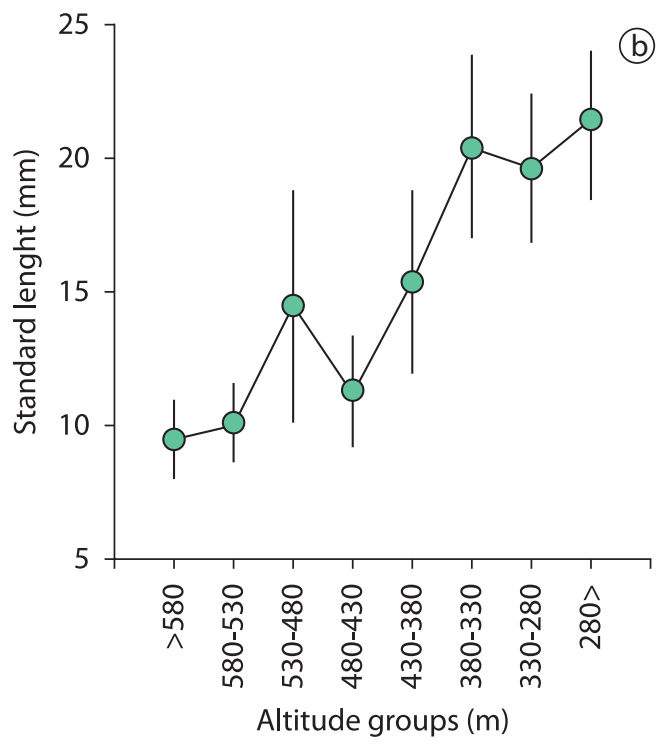

Figure 4. Histogram of Standard length for all sampled species (a) and (b) mean \pm standard error for standard length along a altitudinal gradient in streams of Ivinhema River Basin, Upper Paraná Basin, from 2001 to 2011.

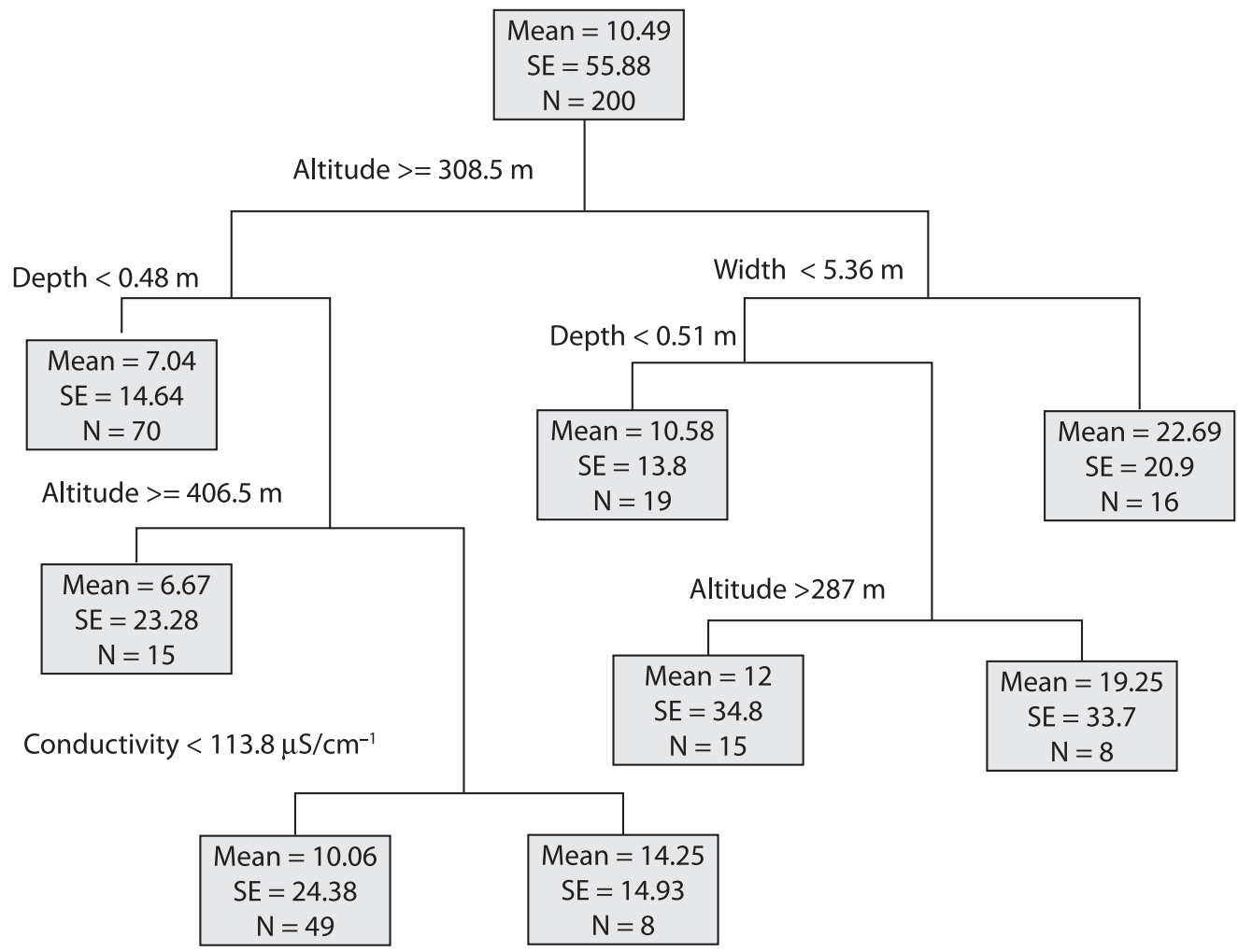

Figure 5. Tree regression of species richness in streams of Ivinhema River Basin, Upper Paraná Basin, from 2001 to 2011. 
and Trichomycterus sp. occurred predominantly in headwater streams. Others, including E. trilineata, F. amazona, $H$. anisitsi, $L$. friderici, $L$. platymetopon, P. galeatus, P. harpagos and P. kennedyi occurred only in streams in the lower portion of the basin. Still other species occurred in the entire basin (Figure 7). A particular case is Poecilia reticulata, which occurred

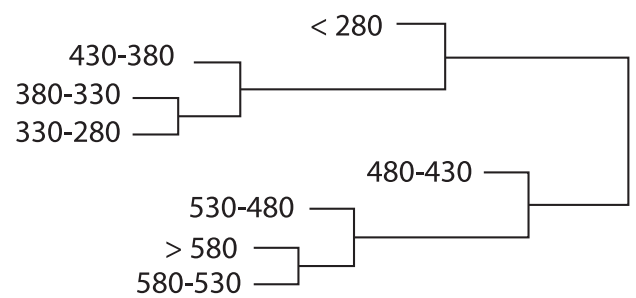

Cophenetic correlation $r=0.70$

$\begin{array}{llllll}0.30 & 0.25 & 0.20 & 0.15 & 0.10 & 0.05\end{array}$

Figure 6. Similarity dendrogram of species composition (Morisita-Horn) along an altitude gradient in streams of Ivinhema River Basin, Upper Paraná Basin from 2001 to 2011 . only in streams from 380 to $480 \mathrm{~m}$ altitude, as a function of its exclusive occurrence in urban streams of Dourados city.

The first two axes of the canonical correspondence analysis explained $71.2 \%$ of the data variation. The first axis explained $45.5 \%$, and the second axis explained $25.7 \%$. All analyzed environmental descriptors had a significant influence on species distribution (Table 1), however altitude was the main determining factor.

Streams located at higher altitudes more often harbored $A$. paranae and $A$. fasciatus. In streams located in the lower portion of the basin, with greater stream width and depth, L. friderici, E. trilineata, $H$. marginatus and $M$. forestii were more common. In streams with higher water conductivity, the most common species were $G$. sylvius and $C$. aeneus, and in streams with higher water velocity, Hisonotus sp., $H$. insperatus, $B$. stramineus, and $P$. argentea, among others, were more common (Figure 8).

A. altiparanae, A. paranae, B. stramineus, C. britskii, C. zebra, H. ancistroides, $H$. iheringii, Hisonotus sp2., I. schubarti, O. pintoi, P. argentea and P. australis

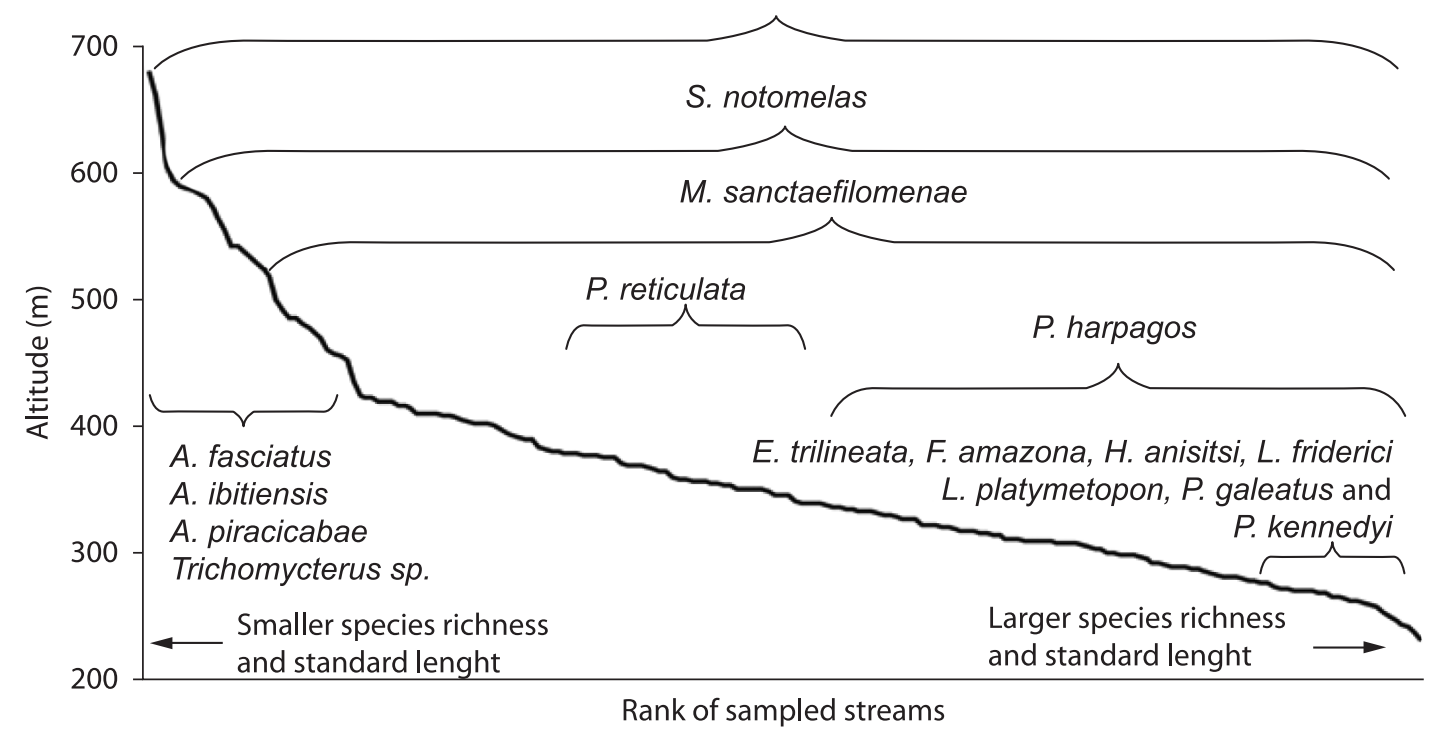

Figure 7. Variation in species distribution along altitude gradient in streams of Ivinhema River Basin, Upper Paraná basin from 2001 to 2011.

Table 1. Results of canonical correspondence analysis for the occurrence of main fish species and environmental descriptors in streams of Ivinhema River basin, Upper Paraná basin, Brazil. ${ }^{* * *}=$ significantly to $\alpha=0.001$.

\begin{tabular}{lccc}
\hline \multicolumn{1}{c}{ Environmental descriptors } & Axis 1 & Axis 2 & $\mathrm{r}^{2}$ \\
\hline Stream width & -0.48 & 0.88 & $0.16^{* * *}$ \\
Stream depth & -0.82 & 0.58 & $0.24^{* * *}$ \\
Water velocity & 0.83 & 0.56 & $0.26^{* * *}$ \\
Altitude & 0.90 & -0.44 & $0.33^{* * *}$ \\
Water conductivity & -0.40 & -0.92 & $0.12^{* * *}$ \\
Statistical summary & & & \\
Explained variation (\%) & $45.5 \%$ & $25.7 \%$ & \\
\hline
\end{tabular}




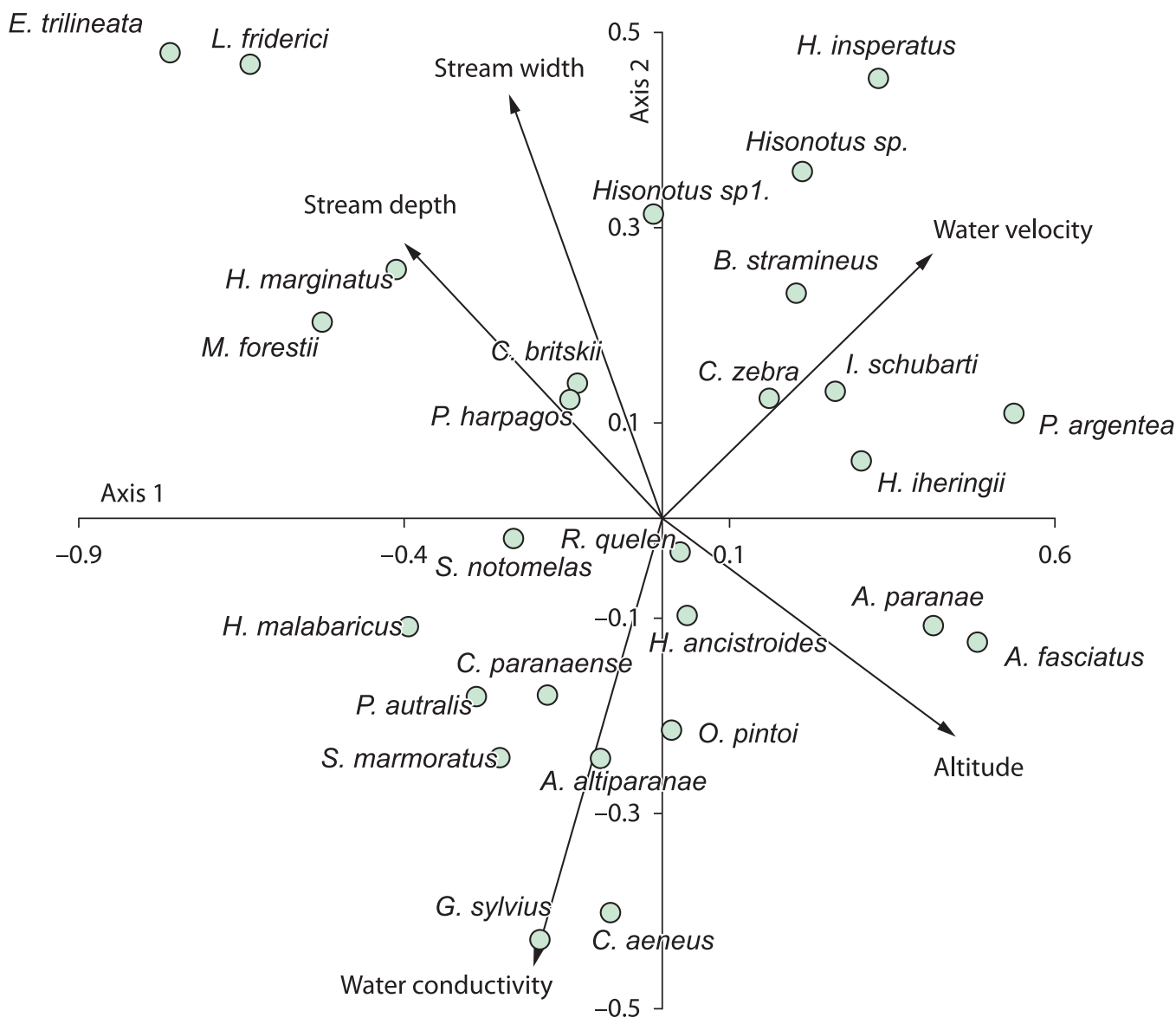

Figure 8. Distribution of fish species along a gradient of altitude in streams of Ivinhema River Basin, Upper Paraná Basin from 2001 to 2011.

\section{Discussion}

The Neotropical freshwater fish community is the most diversified in the world, with approximately 4,500 currently known species and an estimated richness of around 5,000 to 8,000 species (Léveque et al., 2008). In the Upper Paraná River, 310 species, plus 50 other species awaiting descriptions are known so far (Langeani et al., 2007). Our study included $30.8 \%$ of the total species richness in the Upper Paraná basin, which can be considered a relatively large proportion of the total richness, since only streams were sampled and the Ivinhema River basin comprises approximately $5 \%$ of the total area of the Upper Paraná basin.

The observed predominance of Characiformes and Siluriformes was expected, in conformace with the general biogeographical pattern of Neotropical fish assemblages (Castro, 1999). In a recent compilation of species diversity in the Upper Paraná basin, Langeani et al. (2007) found that Characiformes and Siluriformes represent approximately $80 \%$ of the known species; in our study these two orders represented $82.9 \%$ of the species collected. Moreover, while the entire Upper Paraná basin contains $23.9 \%$ allochthonous/exotic species, in our study we found $21.6 \%$ allochthonous species. Therefore, the general patterns of species composition, order distribution, and introduced species are similar to that observed in the Upper Paraná basin as a whole.

The four most common fish species in streams of the Ivinhema River basin are widely distributed in the Upper Paraná basin. it is expected that they will also occur more frequently in the streams sampled, because they are common in the whole Upper Paraná basin (Castro et al., 2003; Castro et al., 2004; Cunico et al., 2009; Dias and Tejerina-Garro, 2010; Teresa and Casatti, 2010). However, some species were recorded for the first time in the Upper Paraná basin ( $C$. australis and $A$. commbrae); and at least $4.5 \%$ of the species collected are undescribed, suggesting the need for increasing fish inventories in this region. 
The streams usually had a low species richness ( $<9$ species), due mainly to small volume of water in the majority of sampled sites. However, species richness varied according to the longitudinal gradient, with relatively few (approximately 20) species occurring in the headwater portions, and more than four times more (90 species) in the lower portion of the basin. This variation in species richness is well explained by the river continuum concept (Vannote et al., 1980), and although the streams are not arranged in a longitudinal continuum, as proposed by the RCC, the same pattern can be seen, because the fish that occur in the upper stretches must overcome the same environmental filters.

Gerhard et al. (2004), studying fish communities in the Brazilian Atlantic Forest, found a bimodal distribution of fish richness ( \pm 2 and 14 species) in streams, associated with stream width, around $3 \mathrm{~m}$ and $10 \mathrm{~m}$ respectively. In our study, only streams located at the lowest altitudes had a different mean width $(6.2 \mathrm{~m})$ compared to the other streams $( \pm 3 \mathrm{~m})$. Therefore, stream width in the streams studied is homogenously distributed in the Ivinhema River basin, and is not the main determinant of species richness.

Grenouillet et al. (2004) detected a clear increase of species richness along a longitudinal gradient, but this pattern is not linear, with a strong spatial autocorrelation, associated with variation in stream size. The longitudinal gradient observed by these authors concords with our data, which showed that longitudinal variation of altitude is the main determinant of species richness, followed by stream depth and width.

Stream depth and width are complementary measures of stream volume, which was one of the most efficient descriptors of species richness, being equivalent to island area in the theory of island biogeography (MacArthur and Wilson, 1967). Therefore, streams with larger volumes (width and depth) have more resources available and consequently support higher species diversity (Gorman and Karr, 1978).

The river continuum concept proposes that physical, chemical and biological alterations along a longitudinal gradient in a watershed network drive the rate of species loss or gain, by the change in the probability of cataclysmic events and processes of channel development. The lower portions of a hydrographic basin have less stressful hydrological conditions compared to headwaters, and support higher species diversity and higher change rate in species composition, explaining the larger total richness when compared to headwaters (Taylor and Warren Junior, 2001; Tondato and Súarez, 2010).

Poff (1997) proposed that hydrological characteristics can select species to colonize each part of a basin, according to their biological traits, and so hydrological variables act as environmental filters for the species. The effect of environmental filters can be viewed in many other regions (Martin-Smith, 1998). For example, in Malayan streams, differences in water velocity define species composition and the variability in species composition. Taylor and Warren Junior (2001) suggested that streams located in the lower portions of a basin have smaller hydrological variations, and consequently their fish assemblages are more influenced by migration. Similarly, Tondato and Súarez (2010) proposed for the Upper Paraguay and Paraná rivers, that altitudinal variation defines the rate of variation in species composition during the year, so streams located in the upper portion will show smaller temporal variations in species composition, while streams in the lower portion are more affected by seasonal migrations.

Pusey et al. (2000), studying fish assemblages in Australian streams, found that the predictability of a fish assemblage structure varies inversely with discharge variability, and landscape factors determine which species may be present at an individual location; however, local factors may determine the relative abundances of individual species. Oberdorff et al. (2001) quantified the relationship between hydrological variability and fish assemblage variability, and proposed that higher environmental variability drives higher variability in fish assemblages, with a higher probability of species extinction. The smaller species richness (accumulated and estimated) in headwater compared to lower stretches of streams can be associated with hydrological hardness (higher water velocity) and higher environmental variability in this part of the basin, possibly selecting only species with a specific morphology adapted to these conditions.

A predominance of smaller-sized species in streams is a general pattern in the Neotropics (Castro, 1999) and is considered a response to higher hydrological variability of streams (paedomorphic character). In our data we also observed this predominance, and a clear pattern of longitudinal increase in species size, mainly below $430 \mathrm{~m}$ of altitude; This suggests that smaller species can show higher population resilience, 
allowing rapid re-colonization of streams after hydrological disturbances related to unpredictable water-level variation in rainy periods. Shibatta and Cheida (2003) analyzing fish size variations in stream fish assemblages of Tibagi River, did not observed significant variation in this variable, what as contradicted in our study, probably by a differences in spatial scale of these studies. Winemiller et al. (2008) commented that the upper and lower stretches of a river harbor fish species with different biological traits, such as adaptations to fast currents, body form, size and adaptations to hydro-geochemical characteristics, then is expected that different portions of the basin had different size distributions.

Our data suggest two zones of fish assemblages in the Ivinhema River basin, corroborated with the indicator values (Indval) result; streams located above $430 \mathrm{~m}$ differ from streams below this altitude in species richness, size and composition. This clear ichthyofauna differentiation among elevation classes concords with other studies that found zonation in fish distribution in a hydrographic basin. Pompeu et al. (2009) detected a clear zonation in fish distribution along an altitudinal gradient in the Upper Capivari River. Ferreira and PetrereJúnior (2009) detected variation in the occurrence and abundance of species and families along an altitudinal gradient in the Itanhaém River basin, with four zones; i.e., a strong gradient of assemblage structure with variations in altitude and the transition from freshwater to estuarine conditions. Similarly, McGarvey (2011), studying fish zonation in two rivers (Chama and Grande) in the USA with a range of $3500 \mathrm{~m}$ altitude, found that the increase in richness downstream was not consistent.

Ferreira and Petrere-Júnior (2009), in addition to well-defined zones, found transitional stretches. These transitions in the Ivinhema River basin were not clear, because in spite of some species that occur in the whole basin, some assemblage characteristics (mean size, species richness and composition) showed different patterns in streams at the same altitude $( \pm 430 \mathrm{~m})$.

All the environmental variables measured had a significant influence on species distribution; however, altitude and water velocity most affected the distributions of the main fish species. The species groups and their relationship to environmental variables were detected in previous studies, on a smaller scale, in the Ivinhema River basin (Súarez, 2008; Súarez and Lima-Júnior, 2009; Felipe and Súarez, 2010) and in other sub-basins of the Upper
Paraná (Casatti et al., 2006; Súarez and PetrereJúnior, 2007). Therefore, the hydrological variables measured are adequate to describe the fish-environment relationship.

Townsend and Hildrew (1994) proposed that, considering a habitat templet for aquatic communities, and the predictability of species' biological traits in response to spatial and temporal gradients, then variability in physical-chemical characteristics and spatial heterogeneity drive community organization, according to the species' biological traits adjusted to specific conditions. Goldstein and Meador (2004) compared fish species traits along a stream size gradient, and proposed that characteristics such as feeding type, reproduction and morphology will show a predictable variation according to stream size.

In conclusion, the organization of an assemblage, including species size, richness and composition, is significantly influenced by hydrological parameters. Altitude, the main factor, can be considered a good surrogate of other hydrological descriptors. Although some species had wider distributional ranges in the basin, a large part occurred mainly in headwaters or in the lower part of the basin. The clear separation into two zones suggests hypothesis about different biological traits in these zones, in response to the hydrological gradient in hydrographic basin. Subsequent studies may explain the relationships between these traits and the environment.

\section{Acknowledgements}

To CNPq and Fundect for financial support. To UEMS for logistical support and a fellowship to the second author. To João Paulo da Silva, Karina K. Tondato, Alexandro C. Florentino, Luzia S. Lourenço and Wagner Vicentin for help in the fieldwork. Y. R. Súarez is supported by productivity grants from $\mathrm{CNPq}$.

\section{References}

Bistoni, MA. and Hued, AC. 2002. Patterns of fish species richness in rivers of the central region of Argentina. Brazilian Journal of Biology, vol. 62, n. 4, p. 753-764. http://dx.doi.org/10.1590/S151969842002000500004

Britski, HA. and Langeani, F. 1988. Pimelodus paranaensis, sp. n. um novo Pimelodidae (Pisces, Siluriformes) do Alto Rio Paraná, Brasil. Revista Brasileira de Zoologia, vol. 5, n. 3, p. 409-417.

Caceres, MD. and Jansen, F. 2010. Indicspecies: Functions to assess the strength and significance of relationship 
of species site group associations. version 1.5.1. Available from: <http://cran.r-project.org/web/ packages/indicspecies/index.html>.

Casatti, L., Langeani, F., Silva, AM. and Castro, RMC. 2006. Stream fish, water and habitat quality in a pasture dominated basin, southeastern Brazil. Brazilian Journal of Biology, vol. 66, n. 2B, p. 681-696. http://dx.doi.org/10.1590/S151969842006000400012

Castro, RMC. 1999. Evolução da ictiofauna de riachos sul-americanos: padróes gerais e possíveis processos causais. In Caramaschi, EP., Mazzoni, R. and PeresNeto, PR., eds. Ecologia de Peixes de Riachos. Rio de Janeiro: PPGE-UFRJ. p. 139-155.

Castro, RMC., Casatti, L, Santos, HF., Ferreira, KM., Ribeiro, AC., Benine, RC., Dardis, GZP., Melo, ALA., Abreu, TX., Bockmann, FA., Carvalho, M., Gibran, FZ. and Lima, FCT. 2003. Estrutura e composição da ictiofauna de riachos do Rio Paranapanema, sudeste e sul do Brasil. Biota Neotropica, vol. 3, n. 1, p. 01-31. Available from: <http://www.biotaneotropica.org.br/ v3n1/pt/abstract?article+BN01703012003>.

Castro, RMC., Casatti, L., Santos, HF., Melo, ALA., Martins, LSF., Ferreira, KM., Gibran, FZ., Benine, RC., Carvalho, M., Ribeiro, AC., Abreu, TX., Bockmann, FA., Dardis, GZP., Stopiglia, R. and Langeani, F. 2004. Estrutura e composição da ictiofauna de riachos da bacia do Rio Grande, no Estado de São Paulo, Sudeste do Brasil. Biota Neotropica, vol. 4, n. 1, p. 01-39. Available from: <http://www.biotaneotropica.org.br/v4n1/pt/ abstract?article+BN0170402004>.

Castro, RMC., Casatti, L., Santos, HF., Vari, RP., Melo, ALA., Martins, LSF., Abreu, TX., Benine, RC., Gibran, FZ., Ribeiro, AC., Bockmann, FA., Carvalho, M., Pelição, GZ., Ferreira, KM., Stopiglia, R. and Akama, A. 2005. Structure and composition of the stream ichthyofauna of four tributary rivers of the upper Rio Paraná basin, Brazil. Ichthyological Explorations of Freshwaters, vol. 16, n. 3, p. 193-214.

Cunico, AM., Graça, WJ., Agostinho, AA., Domingues, WM. and Latini, JD. 2009. Fish, Maringá urban streams, Pirapó river drainage, upper Paraná River basin, Paraná state, Brazil. Check List, vol. 5, n. 2, p. 273-280.

Dauwalter, DC., Splinter, DK., Fisher, WL. and Marston, RA. 2007. Biogeography, ecoregions, and geomorphology affect fish species composition in streams of eastern Oklahoma, USA. Environmental Biology of Fishes, vol. 82, n. 3, p. 237-249.

De'Ath, G. and Fabricius, KE. 2000. Classification and regression trees: a powerful yet simple technique for ecological data analysis. Ecology, vol. 81, 11, p. 3178-3192. http://dx.doi.org/10.1890/00129658(2000)081[3178:CARTAP]2.0.CO;2

Dias, AM. and Tejerina-Garro, FL. 2010. Changes in the structure of fish assemblages in streams along an undisturbed-impacted gradient, upper Paraná River basin, Central Brazil. Neotropical Ichthyology, vol. 8, n. 3, p. 587-598.

Dufrêne, M. and Legendre P. 1997. Species assemblages and indicator species: the need for a flexible asymmetrical approach. Ecological Monographs, vol. 67, p. 345-366.

Felipe, TRA. and Súarez, YR. 2010. Influência dos fatores ambientais nas comunidades de peixes de riachos em duas microbacias urbanas, alto rio Paraná. Biota Neotropica, vol. 10, n. 2, p. 143-151. Available from: <http://www.biotaneotropica.org.br/v10n2/pt/abstr act?article+BN03810022010>.

Ferreira, FC. and Petrere-Júnior, M. 2009. The fish zonation of the Itanhaém river basin in the Atlantic forest of southeast Brazil. Hydrobiologia, vol. 636, p. 1-34.

Gerhard, P., Moraes, R. and Molander, S. 2004. Stream fish communities and their associations to habitat variables in a rain forest reserve in southeastern Brazil. Environmental Biology of Fishes, vol. 71, n. 4, p. 321340. http://dx.doi.org/10.1007/s10641-004-1260-y

Géry, J. 1969. The freshwater fishes of South America. In Fittkau, EJ., Illies, J., Klinge, H., Schwabe, GH. and Sioli, H. Biogeography and Ecology in South America. Springer. 516 p.

Goldstein, RM. and Meador, MR. 2004. Comparisons of fish species traits from small streams to large rivers. Transactions of the American Fisheries Society, vol. 133, p. 971-983. http://dx.doi.org/10.1577/T03-080.1

Gorman, OT. and Karr, JR. 1978. Habitat structure and stream fish communities. Ecology, vol. 59, n. 3, p. 507-515. http://dx.doi.org/10.2307/1936581

Grenouillet, G., Pont, D. and Hérissé, C. 2004. Withinbasin fish assemblage structure: the relative influence of habitat versus stream spatial position on local species richness. Canadian Journal of Fisheries and Aquatic Sciences, vol. 61, p. 93-104. http://dx.doi. org/10.1139/f03-145

Hellmann, JJ. and Fowler, GW. 1999. Bias, precision and accuracy of four measures of species richness. EcologicalApplications, vol. 9, n. 3, p. 824-834. http:// dx.doi.org/10.1890/1051-0761(1999)009[0824:BP $\mathrm{AAOF}] 2.0 . \mathrm{CO} ; 2$

Higgins, CL. 2010. Patterns of functional and taxonomic organization of stream fishes: inferences based on $\alpha, \beta$, and $\gamma$ diversities. Ecography, vol. 33, p. 678-687. http://dx.doi.org/10.1111/j.16000587.2009.05958.x

Hoeinghaus, DJ., Winemiller, KO. and Birnbaum, JS. 2007. Local and regional determinants of stream fish assemblage structure: inferences based on taxonomic vs. functional groups. Journal of Biogeography, vol. 34, p. 324-338. http://dx.doi. org/10.1111/j.1365-2699.2006.01587.x 
Langeani, F., Castro, RMC., Oyakawa, OT., Shibatta, OA., Pavanelli, CS. and Casatti, L. 2007. Diversidade da ictiofauna do Alto Rio Paraná: composição atual e perspectivas futuras. Biota Neotropica, vol. 7, n. 3, p. 181-197. Available from: <http://www. biotaneotropica.org.br/v7n3/pt/abstract?article+ bn03407032007>.

Léveque, C., Oberdorff, T., Paugy, D., Stiassny, MLJ. and Tedesco, PA. 2008. Global diversity of fish (Pisces) in freshwater. Hydrobiologia, vol. 595, p. 545-567.

Marsh-Matthews, E. and Matthews, WJ. 2000. Geographic, terrestrial and aquatic factors: which most influence the structure of stream fish assemblages in the midwestern United States. Ecology of Freshwater Fish, vol. 9, p. 9-21. http://dx.doi.org/10.1034/ j.1600-0633.2000.90103.x

Martin-Smith, KM. 1998. Relationships between fishes and habitat in rainforest streams in Sabah, Malaysia. Journal of Fish Biology, vol. 52, n. 3, p. 458-482.

MacArthur, RH. and Wilson, EO. 1967. The theory of island Biogeography. Princeton: Princeton University Press. 203 p.

McGarvey, DJ. 2011. Quantifying ichthyofaunal zonation and species richness along a $2800-\mathrm{km}$ reach of the Rio Chama and Rio Grande (USA). Ecology of Freshwater Fish, vol. 20, p. 231-242. http://dx.doi. org/10.1111/j.1600-0633.2011.00485.x

Oberdorff, T., Pont, D., Hugueny, B. and Chessel, D. 2001. A probabilistic model characterizing fish assemblages of French rivers: a framework for environmental assessment. Freshwater Biology, vol. 46, p. 399-415. http://dx.doi.org/10.1046/ j.1365-2427.2001.00669.x

Oksanen, J., Blanchet, FG., Kindt, R., Legendre, P., O'Hara, RB., Simpson, GL., Stevens, MHH. and Wagner, H. 2011. Vegan: community ecology package. Version 1.17-11. Available from: <http:// vegan.r-force.r-project.org/>.

Pinto, BCT., Araújo, FG., Rodrigues, VD. and Hughes, RM. 2009. Local and ecoregion effects on fish assemblage structure in tributaries of the Rio Paraíba do Sul, Brazil. Freshwater Biology, vol. 54, p. 26002615.

Poff, NL. 1997. Landscape filters and species traits: towards mechanistic understanding and prediction in stream ecology. , vol. 16, p. 391-409. http://dx.doi. org/10.2307/1468026

Pompeu, PS., Reis, LS., Gandini, CV., Souza, RCR. and Del Favero, JM. 2009. The ichthyofauna of upper rio Capivari: defining conservation strategies based on the composition and distribution of fish species. Neotropical Ichthyology, vol. 7, n. 4, p. 659-666. http://dx.doi.org/10.1590/S167962252009000400015

Pusey, BJ., Kennard, MJ. and Arthington, AH. 2000. Discharge variability and the development of predictive models relating stream fish assemblage structure to habitat in northeastern Australia. Ecology of Freshwater Fish, vol. 9, p. 30-50. http://dx.doi. org/10.1034/j.1600-0633.2000.90105.x

R Development Core Team. 2011. R: A language and environment for statistical computing. [2.12.2] Vienna: R Foundation for Statistical Computing.

Shibatta, OA. and Cheida, CC. 2003. Composição em tamanho dos peixes (Actinopterygii, Teleostei) de ribeiróes da bacia do rio Tibagi, Paraná, Brasil. Revista Brasileira de Zoologia, vol. 20, n. 3, p. 469-473.

Smith, EP. and Van Belle, G. 1984. Nonparametric estimation of species richness. Biometrics, vol. 40, n. 1, p. 119-129. http://dx.doi.org/10.2307/2530750

Súarez, YR. 2008. Variaçáo espacial e temporal na diversidade e composição de espécies de peixes em riachos da bacia do rio Ivinhema, Alto Rio Paraná. Biota Neotropica, v. 8, n. 3, p. 197-204. Available from: <http://www.biotaneotropica.org.br/v8n3/pt/ abstract?article+bn02308032008>.

Súarez, YR. and Lima-Júnior, SE. 2009. Variação espacial e temporal nas assembleias de peixes de riachos na bacia do rio Guiraí, Alto Rio Paraná. Biota Neotropica, vol. 9, n. 1, p. 101-111. Available from: <http:// www.biotaneotropica.org.br/v9n1/pt/abstract?articl e+bn01709012009>.

Súarez, YR. and Petrere-Júnior, M. 2003. Associações de espécies de peixes em ambientes lóticos da bacia do rio Iguatemi, Estado do Mato Grosso do Sul. Acta Scientiarum. Biological Sciences, vol. 25, n. 2, p. 361-367.

Súarez, YR. and Petrere-Júnior, M. 2006. Gradientes de diversidade nas comunidades de peixes da bacia do rio Iguatemi-MS. Iheringia, Série Zoologia, vol. 96, n. 2, p. 197-204.

Súarez, YR. and Petrere-Júnior, M. 2005. Organização das assembleias de peixes em riachos da bacia do rio Iguatemi, Mato Grosso do Sul. Acta Scientiarum Biological Sciences, vol. 22, n. 2, p. 161-167.

Súarez, YR. and Petrere-Júnior, M. 2007. Environmental factors predicting fish community structure in two neotropical rivers in Brazil. Neotropical Ichthyology, vol. 5, n. 1, p. 61-68.

Taylor, CM. and Warren JUNIOr, ML. 2001. Dynamics in species composition of stream fish assemblages: environmental variability and nested subsets. Ecology, vol. 82, n. 8, p. 2320-2330. http://dx.doi. org/10.1890/0012-9658(2001)082[2320:DISCO $\mathrm{S}] 2.0 . \mathrm{CO} ; 2$

Teresa, FB. and Casatti, L. 2010. Importância da vegetação ripária em regiáo intensamente desmatada no sudeste do Brasil: um estudo com peixes de riacho. Pan-American Journal of Aquatic Sciences, vol. 5, n. 3, p. 444-453.

Tondato, KK. and Súarez, YR. 2010. Temporal changes in fish species composition of headwater streams 
of the upper Paraguay and Paraná basins, Brazil. Acta Scientiarum. Biological Sciences, vol. 32, n. 3, p. 279-284.

Townsend, CR. and Hildrew, AG. 1994. Species traits in relation to a habitat templet for river systems. Freshwater Biology, vol. 31, p. 265-275. http://dx.doi. org/10.1111/j.1365-2427.1994.tb01740.x

Turgeon, K. and Rodríguez, MA. 2005. Predicting microhabitat selection in juvenile Atlantic salmon Salmo solar by the use of logistic regression and classification trees. Freshwater Biology, vol. 50, n. 4, p. 539-551. http://dx.doi.org/10.1111/j.13652427.2005.01340.x
Valério, SB., Súarez, YR., Felipe, TRA., Tondato, KK. and Ximenes, LQL. 2007. Organization patterns of headwater-stream fish communities in the Upper Paraguay-Paraná basins. Hydrobiologia, vol. 583, n. 1, p. 241-250.

Vannote, RL., Minshall, GW., Cummins, KW., Sedell, JR. and Cushing, CE. 1980. The river continuum concept. Canadian Journal of Fisheries and Aquatic Sciences, vol. 37, p. 130-137. http://dx.doi. org/10.1139/f80-017

Winemiller, KO., Agostinho, AA. and Caramaschi, EP. 2008. Fish ecology in tropical streams. In Dudgeon, D., ed. Tropical Stream Ecology. Elsevier, Academic Press. 370 p.

Received: 24 August 2011 Accepted: 09 December 2011 